\title{
Chronic urticaria: new management options
}

\author{
Paul A Greenberger
}

\begin{abstract}
Chronic urticaria is defined as episodic or daily hives lasting for at least 6 weeks and impairs quality of life. Two main subtypes include chronic idiopathic (spontaneous) urticaria and inducible (physical) urticaria, but some patients have urticarial vasculitis. "Autoimmune chronic urticaria" implies the presence of histamine releasing or mast cell activating autoantibodies to IgE or FceRl, the high affinity receptor on mast cells and basophils. In patients not readily controlled with labeled dosages of second generation $\mathrm{H}_{1}$ receptor antagonists (antihistamines), there is evidence for reduction of urticaria using up to 4 fold increases in labeled dosages. The biologic modifier, omalizumab, helps to reduce lesions of chronic urticaria within 1-2 weeks.

Keywords: Urticaria, Chronic, Vasculitis, Antihistamine, $\mathrm{H}_{1}$ receptor, Omalizumab, Immunosuppressive
\end{abstract}

\section{Introduction}

The lifetime prevalence of chronic urticaria, defined as episodic or daily hives lasting for 6 weeks, occurs in approximately $1.8 \%$ of the adult population with a period prevalence (past 12 months) of 0.6 to $0.8 \%$ [1-3]. Chronic urticaria occurs in $0.1-0.3 \%$ of children [4]. Besides reducing quality of life and causing absenteeism from school and work [5], the duration of chronic urticaria in adults has been reported to be as follows: $6-12$ weeks in $52.8 \%$, $3-6$ months in $18.5 \%, 7-12$ months in $9.4 \%, 1-5$ years in $8.7 \%$ and over 5 years in $11.3 \%$ [3]. For perspective, the lifetime prevalence of acute urticaria is $8-20 \%$ [1-3].

\section{Histology of chronic urticaria}

Histologic examination of lesional biopsies of patients with chronic urticaria may demonstrate distinct findings that include presence of mononuclear cells (CD4+ Th1 and Th2 lymphocytes), eosinophils, neutrophils, both eosinophils and neutrophils, basophils, mast cells (also increased in non-lesional skin), and activated macrophages [6-10]. Some biopies show edema with little or no cellular infiltrate whereas others show "perivasculitis" as there is a mononuclear infiltrate that doesn't damage the vessel wall $[7,10]$ However, there may be leukocytoclastic vasculitis (cellular infiltrates present with damage of the vessel wall, nuclear debris, extravasation of red blood

Correspondence: p-greenberger@northwestern.edu

Division of Allergy-Immunology, Department of Medicine, Northwestern University Feinberg School of Medicine, Chicago, Illinois, 676 N. St. Clair Street, \# 14108, 60611 Chicago, IL, USA cells) despite the phenotype being an urticarial lesion that doesn't leave residual pigment or ecchymosis $[7,10]$. Lesions of chronic idiopathic urticaria are illustrated in Figure 1.

\section{Terminology}

Chronic idiopathic urticaria, which is synonymous with chronic spontaneous urticaria, is a sub-type of chronic urticaria $[2,11,12]$. Other subtypes of chronic urticaria include the physical urticarias, "autoimmune chronic urticaria" and urticarial vasculitis. Physical urticaria (s) may coexist with chronic idiopathic (spontaneous) urticaria. The European Academy of Allergy and Clinical Immunology/Global Allergy and Asthma European Network/European Dermatology Foundation/World Allergy Organization (EAACI/ GA $^{2}$ LEN/EDF/WAO) guideline [11] and the World Allergy Organization [2] make a designation of inducible urticarias (dematographic, cold by contact, delayed pressure, heat by contact, solar, aquagenic, cholinergic, contact, and vibratory). "Autoimmune" chronic urticaria implies presence of histamine releasing or mast cell activating autoantibodies to $\operatorname{IgE}$ or FceRI and is a subtype of chronic idiopathic (spontaneous) urticaria $[2,11,12]$.

\section{Approach to the patient}

In planning treatments, it is helpful to consider some unfavorable prognostic factors listed in Table 1 [2,4,13-21]. The list primarily is based on studies of adults; physical urticaria is recognized as an unfavorable prognostic factor in children [4]. If a skin biopsy is available, it may be 


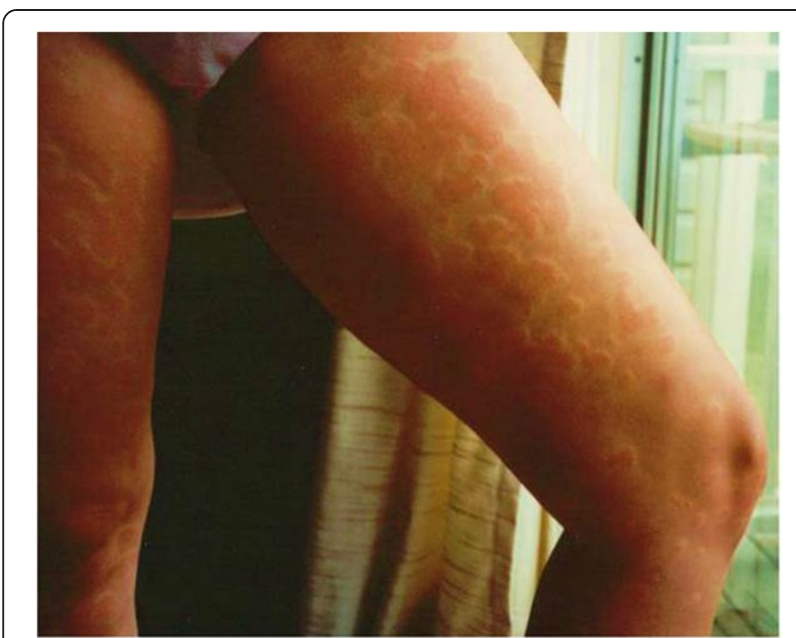

Figure 1 There are plaque like erythematous lesions on the legs in a woman with $\mathrm{H}_{1}$ receptor antagonist resistant chronic urticaria.

informative but often patients with anti-histamine resistant chronic urticaria do not have underlying urticarial vasculitis. The medical record should list the treatments (and their dosages) that have been tried, extent of reduction of pruritus, hives and angioedema, and what any untoward reactions were. The patient's mental outlook should be assessed regarding chronic urticaria and its treatment. Some patients may doubt that a physician or healthcare professional can be helpful because of the persistence of chronic urticaria or have become nihilistic about the benefit-risk ratio of any new or previously untried treatment. Will you be able to create a partnership with the patient with shared goals for treatments and their monitoring?

Table 1 Factors associated with longer duration or more difficult to treat chronic urticaria

\begin{tabular}{|c|c|}
\hline Factor & Comment \\
\hline $\begin{array}{l}\text { Failure of a single labeled dose of an } \mathrm{H}_{1} \\
\text { receptor blocker to control chronic urticaria }\end{array}$ & Explore quality of life \\
\hline \multicolumn{2}{|l|}{$\begin{array}{l}\text { Long duration ( } 6 \text { months or more) } \\
\text { at time of presentation }\end{array}$} \\
\hline Angioedema & Up to $40 \%$ of patients \\
\hline Physical Urticaria & $\begin{array}{l}\text { Inquire about and test where } \\
\text { indicated }\end{array}$ \\
\hline \multicolumn{2}{|l|}{ Autoimmunity diseases/test results* } \\
\hline $\begin{array}{l}\text { Positive autologous serum or plasma } \\
\text { intradermal skin test (some studies) }\end{array}$ & $\begin{array}{l}\text { Use upmost caution with } \\
\text { sera and plasma }\end{array}$ \\
\hline \multicolumn{2}{|l|}{ Serum IgG anti-lgE or lgG anti-FcعRI } \\
\hline \multicolumn{2}{|l|}{ Hypertension } \\
\hline \multicolumn{2}{|l|}{$\begin{array}{l}\text { Subclinical activation of the extrinsic } \\
\text { coagulation pathway (Prothrombin } \\
\text { fragments detected) or evidence of } \\
\text { fibrinolysis (D-Dimer }>500 \mathrm{ng} / \mathrm{mL} \text { ) }\end{array}$} \\
\hline Basophil activation (CD203c+) & \\
\hline
\end{tabular}

*Applies to adults but not children for thyroid pathology/autoantibodies. References for Table 1: [2,4,13-21].

\section{New treatment approaches as options for persisting, troublesome chronic urticaria Biologic therapy}

Omalizumab is effective in anti-histamine resistant chronic urticaria [22-28]. In contrast to treatment of persistent severe asthma where a patient may need to be assessed after 4-6 months of administration of omalizumab, reductions of pruritus and urticarial lesions occur within a 1 week of a single subcutaneous injection of 150 or $300 \mathrm{mg}$ [22]. The severity and duration of chronic urticaria in the study subjects are illustrated by the means of 4.3 medications used and duration of lesions being 6.8 years [22]. The subjects were assessed according to an itch-severity scoring system where the highest score of 21 represented the most symptoms and impact. The baseline score (mean of 14) was compared to the last week of a 12 week active interval [22]. The placebo arm subjects took 1 second generation $\mathrm{H}_{1}$ receptor antagonist they had used prior to beginning the omalizumab-placebo with diphenhydramine rescue. The reduction in itch/severity score was $36 \%$ for the placebo subjects compared with $70 \%$ for active treatment with omalizumab $300 \mathrm{mg}$ [22]. Thus, the number needed to treat (NNT) to benefit 1 patient is calculated as $1 /$ absolute benefit increase or

$$
\begin{aligned}
\mathrm{NNT}= & 1 / \text { experimental result rate-control rate } \\
& \text { expressed as decimals and an absolute } \\
& \text { number or } 1 / 0.70-0.36=1 / 0.34 \text { or } 2.9 \ldots \\
& \text { an extremely impressive result. }
\end{aligned}
$$

Omalizumab is approved for use in the U.S. for chronic idiopathic urticaria that is not controlled by $\mathrm{H}_{1}$ receptor antagonists for patients ages 12 years and older. The dosage is either $150 \mathrm{mg}$ or $300 \mathrm{mg}$ subcutaneously every 4 weeks. No new safety issues have been identified in treatment of patients with chronic urticaria which is reassuring. The rapid response may be a reflection of the 1) binding of omalizumab to free IgE antibodies, which occurs within a few hours of administration, that reduces the binding of IgE to the high affinity receptor FceRI on basophils and mast cells, and 2) downregulation of the expression of FceRI on whole blood basophils (within 2 weeks) and mast cells (within 8 weeks) [22]. If pharmacologic effects can be extrapolated from experiments in patients with allergic rhinitis, omalizumab has been associated with both a reduction in the allergen induced wheal size and recruitment of eosinophils into the late phase skin reaction [29]. Eosinophils are present in some patients with chronic urticaria, and activation of eosinophils in lesional skin has been demonstrated by staining for major basic protein in extracellular tissue [30]. In that major basic protein can activate mast cells [31], perhaps the anti-eosinophil effect of omalizumab 
is another mechanism for the reduction in lesions of chronic idiopathic (spontaneous) urticaria in some patients.

The duration of treatment remains to be established. When study patients were observed for an additional 20 weeks after the third and last injection of omalizumab at 8 weeks, there was a gradual return of pruritus and urticaria by week 20 , the data suggesting a treatment duration of about 4 weeks with subsequent loss of efficacy. This finding suggests the need for longer term treatment for some patients. While patients with persistent moderate and severe asthma may discontinue treatment with omalizumab, it is usually because of lack of benefit not ontoward effects. Similar to other medications or interventions, the decision to continue omalizumab for chronic urticaria should include assessing therapeutic benefit and any untoward effects.

\section{Higher dosages of $\mathrm{H}_{1}$ receptor antagonists}

Up to 4 times the labeled adult dosages of second generation $\mathrm{H}_{1}$ receptor antagonists, levocetirizine and desloratadine, have been shown to reduce symptoms in about $75 \%$ of patients with chronic idiopathic urticaria (including patients with concomitant physical urticaria) [32]. The 80 randomized patients with "difficult to treat" chronic urticaria included $58(72.5 \%)$ patients who had received oral corticosteroids within the previous 3 weeks. The study patients had not achieved control with both first and/or second generation $\mathrm{H}_{1}$ receptor antagonists. The study design was randomized, blinded, with crossover active treatment of either levocetirizine or desloratadine, both starting at $5 \mathrm{mg}$. At 1 week intervals, the dosage of $\mathrm{H}_{1}$ receptor antagonist was increased to $10 \mathrm{mg}$ then $20 \mathrm{mg}$ if control had not been achieved. If subjects became symptom and urticaria free for 3 days ("success"), they didn't continue to the crossover arm of the study. The study results included the following observations: [1] doubling the dosage to $10 \mathrm{mg}$ was effective with both active treatments; [2] the initial success rate (increasing to $20 \mathrm{mg}$ if needed) was superior with levocetirizine (22/40 subjects) compared with desloratadine (I2/37 subjects); [3] when symptomatic subjects were switched to the alternative treatment arm, therapeutic benefit occurred with levocetirizine but not desloratadine. For example, there were $7 / 25$ subjects not achieving success with desloratadine $20 \mathrm{mg}$ who became symptom free with levocetirizine $20 \mathrm{mg}$ [32]. Alternatively, $0 / 18$ subjects who had not reached success with levocetirizine $20 \mathrm{mg}$ improved with desoloratadine $20 \mathrm{mg}$ [32]; [4] somnolence was either unchanged from baseline or lower with both active treatments. The WAO Scientific and Clinical Issues Council and EAACI/ $\mathrm{GA}^{2} \mathrm{LEN} / \mathrm{EDF} / \mathrm{WAO}$ guidelines suggest that instead of using oral corticosteroids as second-line treatment for patients with chronic urticaria, higher doses of second generation $\mathrm{H}_{1}$ receptor antagonists should be tried $[2,11]$.

\section{Older drugs with effectiveness for persisting, troubling chronic urticaria \\ Tricyclic antidepressants}

The tricyclic antidepressant, doxepin, has been studied in 2 double blind, controlled trials [33,34]. While doxepin has been administered for at least 30 years, it remains a potent $\mathrm{H}_{1}$ (and $\mathrm{H}_{2}$ receptor) receptor antagonist and is effective in some patients without either intolerable or any perceived drowsiness. In a study of 50 patients, doxepin $10 \mathrm{mg}$ three times daily was compared with diphenhydramine $25 \mathrm{mg}$ three times daily [33]. "Total clearing of the pruritus and urticarial lesions occurred in $43 \%$ of the patients while receiving doxepin and in only $5 \%$ while receiving diphenhydramine" [33]. And in another study in 16 adults, doxepin was superior to placebo and reduced the cutaneous wheals produced by histamine and codeine [34]. Anti-cholinergic side effects such as constipation and dry mouth may occur in addition to sedation. However, doxepin (and other tricyclic antidepressants such as nortriptyline) may be beneficial in difficult to treat chronic urticaria.

\section{Leukotriene receptor antagonists}

Because intradermal injections of very small dosages of $\mathrm{LTD}_{4}$ cause wheal/erythema reactions $[35,36]$, the leukotriene receptor antagonists zafirlukast [37] and montelukast $[38,39]$ have been tested in patients with chronic idiopathic urticaria. In a 2 arm, placebo-controlled trial, the addition of zafirlukast $20 \mathrm{mg}$ twice daily to cetirizine $10 \mathrm{mg}$ daily resulted in a "modest but significant" reduction in a visual analogue scale when assessed over a 3 week period compared with cetirizine monotherapy [37]. In retrospect, those patients who had a positive autologous serum skin test response were more likely to respond to montelukast as "add-on" therapy [37]. In a double-blind, crossover, placebo-controlled study, there was no difference between montelukast, $10 \mathrm{mg}$, and placebo (including in patients with concomitant aspirin intolerance) as add-on therapy [39]. A systematic review in 2009 concluded that "montelukast might be effective in chronic urticaria associated with aspirin (ASA) or food additive hypersensitivity or with autoreactivity to intradermal serum injection (ASST) when taken with an antihistamine but not in mild or moderate chronic idiopathic urticaria (urticaria without any possible secondary causes...)" [40]. The literature suggests that if a response to a leukotriene receptor antagonist is likely, it occurs over the first 3 weeks. Thus, a patient could be tried for 3-4 weeks and if no symptomatic response occurs, the leukotriene receptor antagonist would be discontinued. 
It is of interest that leukotriene receptor antagonists have been reported to be effective in some types of physical urticaria such as primary cold urticaria, delayed pressure urticaria and dermatographism [40].

\section{Immunosuppressive drugs}

The immunosuppressive drugs may be therapeutic as monotherapy for patients with uncontrolled chronic urticaria. There may be a clear-cut response to immunosuppressive drugs in the initial 1-4 weeks of therapy. Some patients respond after 3-5 months of treatment. Benefit-risk considerations should be assessed, and patients must be monitored for clinical harm and laboratory abnormalities. Cyclosporine [41-45], tacrolimus [46], mycophenolate mofetil $[47,48]$, methotrexate [49], azathioprine [50] and mizoribine [51] have been found effective in some patients with refractory, typically prednisonedependent chronic urticaria. There are various reviews of the treatment choices when patients have failed multiple other therapies [52-56]. The daily dosages of cyclosporine initially were $5 \mathrm{mg} / \mathrm{kg}$ but to avoid hypertension and loss of renal function (often reversible), lower dosages have been utilized such as $1.5-2.5 \mathrm{mg} / \mathrm{kg}$ daily [41]. The patient monitors blood pressure twice a week and renal function is checked every 2 weeks at first. If the serum creatinine increases $30 \%$, the dosage of cyclosporine is reduced. If the creatinine doesn't return to baseline in 2 more weeks, (after a month of increase), the decision can be made to discontinue treatment [41]. The daily dosage of tacrolimus was reported as high as with $0.05-0.07 \mathrm{mg} / \mathrm{kg}$ twice daily for 4 weeks then reduced by $1 / 2$ for 6 weeks [46]. Eventually the dosage was $1 \mathrm{mg}$ daily. Because of side effects (abdominal pain, diarrhea, headache, etc.), this author starts with $5 \mathrm{mg}$ daily for adults to determine tolerability and safety. Khan has suggested beginning at $1 \mathrm{mg}$ twice daily [52]. Mycophenolate mofetil, which doesn't cause renal impairment but can increase the risk for infections, has a starting dosage of $1000 \mathrm{mg}$ twice daily [52]. Azathioprine can cause acute abdominal pain, nausea, arthralgias, abnormal liver function tests and cytopenias and also may be effective as monotherapy. This author initiates therapy in adults with $100 \mathrm{mg}$ daily. Laboratory tests should be obtained every 2 weeks for the first 2 months then at a lesser interval if there is a response to azathioprine.

\section{Miscellaneous agents}

Colchicine [57-59], dapsone [60-62] and sulfasalazine $[63,64]$ have anti-inflammatory effects that may contribute to reduction in the frequency and severity of urticarial lesions in treatment-resistant chronic urticaria. These agents have specific adverse effects such as diarrhea for colchicine, hemolysis and methemoglobinemia (even in glucose 6 phosphate dehydrogenase sufficient patients) for dapsone, and gastrointestinal symptoms, headache, rash, leukopenia and elevated liver function tests for sulfasalazine. Most experience is from retrospective reviews. Starting dosages in adults are as follows: colchicine $0.6 \mathrm{mg}$ daily for a week then twice daily [57]; 25-100 mg daily for dapsone; and $500 \mathrm{mg}$ daily increasing weekly to $2000 \mathrm{mg}$ daily for sulfasalazine [64].

In that elevated concentrations of D-dimer reflect activation of the external pathway of the coagulation system and evidence of fibrinolysis, patients with treatment-resistant chronic urticaria received a low molecular weight heparin, nadroparin (11,400 IU) daily and oral tranexamic acid as an inhibitor of fibrinolysis [65]. There was "marked improvement" within 2 weeks in $5 / 8$ patients [65]. The concentration of D-dimer declined in responders and non-responders. It is suspected that tissue factor, which activates the coagulation cascade, is derived from eosinophils in chronic urticaria [66]. Warfarin has been reported as a possible treatment in a small double-blind, controlled, crossover trial in which the International Normalized Ratio (INR) was between 2.0 and 2.5 [67]. In patients who improved, there was no reduction in the response to intradermal injections of histamine or the mast cell activator, compound 48/80 [67]. Besides inhibiting thrombin and reducing synthesis of protein $\mathrm{C}$ and the vitamin K-dependent factors (prothrombin and VII, IX, and $\mathrm{X}$ ), warfarin reduces generation of kinin, activation of complement, and down-regulates vascular adhesion molecules.

Approved for Leishmaniasis because of its antitrypanosomatid parasite activity and recognized as a drug with antineoplastic effects, the protein kinase B inhibitor, miltefosine, was reported to reduce the urticaria activity score in antihistamine resistant patients (UAS7) over a 4 week period compared with placebo [68]. The intensity of pruritus was not lessened. Side effects include vomiting, diarrhea, elevated liver function tests and increases in serum creatinine. How miltefosine will be used in difficult to control chronic urticaria remains to be determined.

\section{Summary}

Chronic urticaria impairs quality of life and in about $1 / 2$ of patients doesn't respond readily to labeled dosages of a single $\mathrm{H}_{1}$ receptor antagonist. While increasing the dosage up to 4 fold of a second generation agent, levocetirizine [32] or desloratadine [32] has been shown to be useful in some patients, this is roughly equivalent to using potent and long lasting first generation $\mathrm{H}_{1}$ receptor antagonists (wherein hydroxyzine $25 \mathrm{mg}$ is comparable to cetirizine $10 \mathrm{mg}$ ) [54]. The opportunity to treat with omalizumab for chronic idiopathic (spontaneous) urticaria provides a safe approach that has resulted in reduction in pruritus and number of hives within a week of the first subcutaneous dosage [22]. The number of 
patients to treat to benefit 1 patient with omalizumab is 2.9 , a very favorable (low) number. It will be important to determine if longer term treatment can cause disease remission.

\section{Competing interests}

The author declares he has no competing interests related to this paper.

\section{Authors' contributions}

PG drafted and completed this manuscript. PG approves the final version.

\section{Acknowledgements}

The development of this paper is supported by the Ernest S. Bazley Trust to Northwestern Memorial Hospital and Northwestern University.

Support for the dissemination of the WAO Immunotherapy and Biologics Online Monograph is provided by the following sponsors: Circassia,

Boehringer-Ingleheim, and ORA Inc.

Received: 17 April 2014 Accepted: 30 September 2014 Published: 5 November 2014

\section{References}

1. Zuberbier T, Balke M, Worm M, Edenharter G, Mauer M: Epidemiology of urticaria: a representative cross-sectional population survey. Clin Exper Dermatol 2010, 35:869-73.

2. Sanchez-Borges M, Asero R, Ansotegui IJ, Baiardini I, Bernstein JA, Canonica GW, Gower R, Kahn DA, Kaplan AP, Katelaris C, Maurer M, Park HS, Potter P, Saini S, Tassinari P, Tedeschi A, Ye YM, Zuberbier T, WAO Scientific and Clinical Issues Council: Diagnosis and treatment of urticaria and angioedema: a worldwide perspective. WAO J 2012, 5:125-47.

3. Gaig P, Olona M, Munoz Lejarazu D, Caballero MT, Dominguez FJ, Echechipia S, Garcia Abujeta JL, Gonzalo MA, Lleonart R, Martinez Cocera C, Rodriguez A, Ferrer M: Epidemiology of urticaria in Spain. J Invest Allergol Clin Immunol 2004, 14:214-20.

4. Kkakoo G, Sofianou-Katsoulis A, Perkin MR, Lack G: Clinical features and natural history of physical urticaria in children. Pediatr Allergy Immunol 2008, 19:363-6.

5. Ferrer M: Epidemiology, healthcare, resources, use and clinical features of different types of urticaria. Allergologica 2005. J Investig Allergol Clin Immunol 2009, 19(Suppl 2):21-6.

6. Elias J, Boss E, Kaplan AP: Studies of the cellular infiltrate of chronic idiopathic urticaria: prominence of T-lymphocytes, monocytes, and mast cells. J Allergy Clin Immunol 1986, 78:914-18.

7. Farkas Natbony S, Phillips ME, Elias JM, Godfrey HP, Kaplan AP: Histologic studies of chronic idiopathic urticaria. J Allergy Clin Immunol 1983, 71:177-83.

8. Haas N, Toppe E, Henz BM: Microscopic morphology of different types of urticaria. Arch Dermatol 1998, 134:41-46.

9. Sabroe RA, Poon E, Orchard GE, Lane D, Francis DM, Barr RM, Black MM, Black AK, Greaves MW: Cutaneous inflammatory cell infiltrate in chronic idiopathic urticaria: a comparison of patients with and without anti-FcepsilonRI or anti-IgE autoantibodies. J Allergy Clin Immunol 1999, 103:484-93.

10. Phanuphak P, Kohler PF, Stanford RE, Schocket AL, Carr RI, Claman HN: Vasculitis in chronic urticaria. J Allergy Clin Immunol 1980, 65:436-44

11. Zuberbier T, Aberer W, Asero R, Bindslev-Jensen C, Brzoza Z, Canonica GW, Church MK, Ensina LF, Gimenez-Arnau A, Godse K, Goncalo M, Grattan C, Hebert J, Hide M, Kaplan A, Kapp A, Abdul Latiff AH, Mathelier-Fusade P, Metz M, Nast A, Saini SS, Sanchez-Borges M, Schmid-Grendelmeier P, Simons FER Staubach P, Sussman G, Toubi E, Vena GA, Wedi B, Zhu XJ, Maurer M: The EAACI/GA 2 LEN/EDF/WAO Guideline for the definition, classification, diagnosis, and management of urticaria: the 2013 revision and update. Allergy 2014, 69:868-87.

12. Bernstein JA, Lang DM, Khan DA, Craig T, Dreyfus D, Hsieh F, Sheikh J, Weldon D, Zuraw B, Bernstein DI, Blessing-Moore J, Cox L, Nicklas RA, Oppenheimer J, Portnoy JM, Randolph CR, Schuller DE, Spector SL, Tilles SA, Wallace $D$ : The diagnosis and management of acute and chronic urticaria: 2014 update. J Allergy Clin Immunol 2014, 133:1270-7. 10.1016/j.jaci.2014.02.036.

13. Van Der Valk PGM, Moret G, Kiemeney ALM: The natural history of chronic urticaria and angioedema in patients visiting a tertiary referral centre. Br J Dermatol 2002, 146:110-13.
14. Hiragun M, Hiragun T, Mihara S, Akita T, Tanaka J, Hide M: Prognosis of chronic spontaneous urticaria in 117 patients not controlled by a standard dose of antihistamine. Allergy 2013, 68:229-35.

15. Sahiner UM, Civelek E, Tuncer A, Tolga Yavuz S, Karablut E, Sackesen C, Sekerel BE: Chronic urticaria: Etiology and natural course in children. Int Arch Allergy Immunol 2011, 156:224-30.

16. Rabelo-Filardi R, Daltro-Oliveira R, Campos RA: Parameters associated with chronic spontaneous urticaria duration and severity: a systematic review. Int Arch Allergy Immunol 2013, 161:197-204.

17. Nebiolo F, Bergia R, Bommarito L, Bugiani M, Heffler E, Carosso A, Castiglioni G, Guida G, Badiu I, Pizzimenti S, Mietta S, Ferrero N, Rolla G: Effect of arterial hypertension on chronic urticaria duration. Ann Allergy Asthma Immunol 2009, 103:407-10.

18. Ye Y-M, Yang E-M, Yoo H-S, Shin Y-S, Kim S-H, Park H-S: Increased level of basophil CD203c expression predicts severe chronic urticaria. J Korean Med Sci 2014, 29:43-7.

19. Asero R: D-dimer: a biomarker for antihistamine-resistant chronic urticaria. J Allergy Clin Immunol 2013, 132:983-5.

20. Toubi E, Kessel A, Avshovich N, Bamberger E, Sabo E, Nusem D, Panasoff J: Clinical and laboratory parameters in predicting chronic urticaria duration: a prospective study of 139 patients. Allergy 2004, 59:869-73.

21. Magen E, Mishal J, Zeldin Y, Schlesinger M: Clinical and laboratory features of antihistamine-resistant chronic idiopathic urticaria. Allergy Asthma Proc 2011, 32:460-6.

22. Maurer M, Rosen K, Hsieh H-J, Saini S, Grattan C, Gimenez-Arnau A, Agarwal S, Doyle R, Canvin J, Kaplan A, Casale T: Omalizumab for the treatment of chronic idiopathic or spontaneous urticaria. N Engl J Med 2013, 368:924-35.

23. Vestergaard C, Deleuran M: Two cases of severe refractory chronic idiopathic urticaria treated with omalizumab. Acta Derm-Venereol 2010, 90: doi:10.2340/00015555-0884.

24. Metz M, Ohanyan T, Church MK, Maurer M: Omalizumab is an effective and rapidly acting therapy in difficult-to-treat chronic urticaria: a retrospective clinical analysis. J Dermato Sci 2013, 73:57-62.

25. Saavedra M, Sur S: Down regulation of the high-affinity IgE receptor associated with successful treatment of chronic idiopathic urticaria with omalizumab. Clin Molec Allergy 2011, 9:2.

26. Saini S, Rosen KE, Hsieh H-J, Wong DA, Conner E, Kaplan A, Spector S, Maurer M: A randomized, placebo-controlled, dose ranging study of single-dose omalizumab in patients with $\mathrm{H} 1$-antihistamine refractory chronic idiopathic urticaria. J Allergy Clin Immunol 2011, 128:567-73.

27. Kaplan A, Ledford D, Ashby M, Canvin J, Zazzali JL, Conner E, Veith J, Kamath N, Stabach P, Jakob T, Stirling RG, Kuna P, Berger W, Maurer M, Rosen K: Omalizumab in patients with symptomatic chronic idiopathic/ spontaneous urticaria despite standard combination therapy. J Allergy Clin Immunol 2013, 132:101-9.

28. Sussman G, Hebert J, Barron C, Bian J, Caron-Guay RM, Laflamme S, Stern S: Real-life experiences with omalizumab for the treatment of chronic urticaria. Ann Allergy Asthma Immunol 2013, 112:170-4.

29. Beck LA, Marcotte GV, MacGlashan D, Togias A, Saini S: Omalizumab-induced reductions in mast cell FcERI expression and function. J Allergy Clin Immunol 2004, 114:527-30.

30. Kay AB, Ying S, Ardelean E, Mlynek A, Kita H, Clark P, Maurer M: Elevations in vascular markers and eosinophils in chronic spontaneous urticarial weals with low-level persistence in uninvolved skin. Br J Dermatol 2014, 171:505-11.

31. Piliponsky AM, Gleich GJ, Bar I, Levi-Schaffer F: Effects of eosinophils on mast cells: a new pathway for the perpetuation of allergic inflammation. Mol Immunol 2001, 38:1369-72

32. Staevska M, Todor TA, Kralimarkova T, Lazarova C, Kraeva S, Popova D, Church DS, MD, Dimitrov V, Church MK: The effectiveness of levocetirizine and desloratadine in up to 4 times the conventional doses in difficult-totreat urticaria. J Allergy Clin Immunol 2010, 125:676-82.

33. Greene SL, Reed CE, Schroeter AL: Double-blind crossover study comparing doxepin with diphenhydramine for the treatment of chronic urticaria. J Am Acad Dermatol 1985, 12:669-75.

34. Goldsobel AB, Rohr AS, Siegel SC, Spector SL, Katz RM, Rachelefsky GS, Drayton G, Indianer L, Peter JB, Barr RJ, et al: Efficacy of doxepin in the treatment of chronic idiopathic urticaria. J Allergy Clin Immunol 1986, 78:867-73. 
35. Bernstein JA, Greenberger PA, Patterson R, Glass M, Krell R, Thyrum PT: The effect of the oral leukotriene antagonist, ICI 204, 219, on leukotriene $\mathrm{D}_{4}$ and histamine-induced cutaneous vascular reactivity in man. $J$ Allergy Clin Immunol 1991, 87:93-8.

36. Soter NA, Lewis RA, Corey EJ, Austen KF: Local effects of synthetic leukotrienes $\left(\mathrm{LTC}_{4}, \mathrm{LTD}_{4}, \mathrm{LTE}_{4}\right.$, and $\left.\mathrm{LTB}_{4}\right)$ in human skin. J Invest Derm 1983, 80:115-9.

37. Bagenstose SE, Levin L, Bernstein JA: The addition of zafirlukast to cetirizine improves the treatment of chronic urticaria in patients with positive autologous serum skin test results. J Allergy Clin Immunol 2004, 113:134-40

38. Erbagci $Z$ : The leukotriene receptor antagonist montelukast in the treatment of chronic idiopathic urticaria: A single-blind, placebo-controlled, crossover clinical study. J Allergy Clin Immunol 2002, 110:484-8.

39. Kosnik M, Subic T: Add-on montelukast in antihistamine-resistant chronic idiopathic urticaria. Resp Med 2011, 105:S84-S88.

40. Di Lorenzo G, D'Alcamo A, Rizzo M, Leto-Barone MS, Lo Bianco C, Ditta V, Politi D, Castello F, Pepe I, Di Fede G, Rini GB: Leukotriene receptor antagonists in monotherapy or in combination with antihistamines in the treatment of chronic urticaria: a systematic review. J Asthma Allergy 2009, 2:9-16.

41. Boubouka C, Charissi C, Kouimintzis D, Kalogeromitros D, Stavro-Poulos P, Katsarou A: Treatment of autoimmune urticaria with low-dose cyclosporine A: a one-year follow-up. Acta Derm Venerol 2011, 91:50-4.

42. Kessel A, Toubi E: Cyclosporine-A in severe chronic urticaria: the option for long-term therapy. Allergy 2010, 65:1478-82.

43. Vena GA, Cassano N, Colombo D, Peruzzi E, Pigatto P: Cyclosporine in chronic idiopathic urticaria: a double-blind, randomized, placebo-controlled trial. J Am Acad Dermatol 2006, 55:705-9.

44. Inaloz HS, Ozturk S, Akcali C, Kirtak N, Tarakcioglu M: Low-dose and shortterm cyclosporine treatment in patients with chronic idiopathic urticaria: a clinical and immunological evaluation. J Dermatol 2008, 35:276-82.

45. Grattan CE, O'Donnell BF, Francis DM, Niimi N, Barlow RJ, Seed PT, Kobza Black A, Greaves M: Randomized double-blind study of cyclosporine in chronic "idiopathic" urticaria. Br J Dermatol 2000, 143:365-72.

46. Kessel A, Bamberger E, Toubi E: Tacrolimus in the treatment of severe chronic idiopathic urticaria: An open-label prospective study. J Am Acad Dermatol 2005, 52:145-8.

47. Shahar E, Bergman R, Guttman-Yassky E, Pollack S: Treatment of severe chronic idiopathic urticaria with oral mycophenolate mofetil in patients not responding to antihistamines and/or corticosteroids. Int J Dermatol 2006, 45:1224-7.

48. Zimmerman AB, Berger EM, Elmariah SB, Soter NA: The use of mycophenolate mofetil for the treatment of autoimmune and chronic idiopathic urticaria: experience in 19 patients. J Am Acad Dermatol 2011, 66:767-70.

49. Perez A, Woods A, Grattan CEH: Methotrexate: a useful steroid-sparing agent in recalcitrant chronic urticaria. Br J Dermatol 2010, 162:191-4.

50. Tedeschi A: Paradoxical exacerbation of chronic urticaria by $\mathrm{H} 1$-antihistamines and montelukast. Eur Ann Allergy Clin Immunol 2009, 41:187-9.

51. Hashimoto T, Kawakami T, Ishii N, Ishii K, Karashima T, Nakama T, Tsuruta D, Dainichi T, Hide M, Hamada T: Mizoribine treatment for antihistamine-resistant chronic autoimmune urticaria. Dermatol Ther 2012, 25:379-81.

52. Khan DA: Alternative agents in refractory chronic urticaria: Evidence and considerations on their selection and use. J Allergy Clin Immunol: In Practice 2013, 1:433-40.

53. Aseri R, Tedeschi A, Cugno M: Treatment of refractory chronic urticaria: current and future therapeutic options. Am J Clin Dermatol 2013, 14:461-8.

54. Kaplan AP: Treatment of chronic spontaneous urticaria. Allergy Asthma Immunol Res 2012, 4:326-331.

55. Joint Task Force on Practice Parameters: The diagnosis and management of urticaria: a practice parameter part l:acute urticaria/angioedema part II: chronic urticaria/angioedema. Ann Allergy Asthma Immunol 2000, 85:521-44.

56. Ortonne J-P: Chronic urticaria: a comparison of management guidelines. Expert Opinion Pharmacother 2011, 12:2683-93.

57. Georgy MS, Grammer LC, Greenberger PA, Peters AT: A retrospective chart review of the use of colchicine for the treatment of refractory chronic idiopathic urticaria. J Allergy Clin Immunol 2010, 125:AB96.

58. Martinez BA, Hanson IC, Davis CM: Colchicine use in resistant urticaria and angioedema patients: a case series. J Allergy Clin Immunol 2007, 119:S200.
59. Pho LN, Eliason MJ, Regruto M, Hull CM, Powell DL: Treatment of chronic urticaria with colchicine. J Drugs Dermatol 2011, 10:1423-8.

60. Engin B, Ozdemir M: Prospective randomized non-blinded clinical trial on the use of dapsone plus antihistamine vs. antihistamine in patients with chronic idiopathic urticaria. J Eur Acad Dermatol Venereol 2008, 22:481-6.

61. Cooke AJ, Morgan M, Rogers L, Huet-Adams B, Khan DA: Double-blind placebo controlled (DBPC) trial of dapsone in antihistamine refractory chronic idiopathic urticaria (CIU). J Allergy Clin Immunol 2013, 131:AB143.

62. Cassano N, D'Argento V, Filotico R, Veno GA: Low-dose dapsone in chronic idiopathic urticaria: preliminary results of an open study. Acta Derm Venerol 2005, 85:254-5.

63. McGirt LY, Vasagar K, Gober LM, Saini SS, Beck LA: Successful treatment of recalcitrant chronic idiopathic urticaria with sulfasalazine. Arch Dermatol 2006, 142:1337-42

64. Orden RA, Timble H, Saini SS: Efficacy and safety of sulfasalazine in patients with chronic idiopathic urticaria. Ann Allergy Asthma Immunol 2014, 112:64-70.

65. Asero R, Tedeschi A, Cugno M: Heparin and tranexamic acid therapy may be effective in treatment-resistant chronic urticaria with elevated d-dimer: a pilot study. Int Arch Allergy Immunol 2010, 152:384-9.

66. Cugno M, Marzano AV, Tedeschi A, Fanoni D, Venegoni L, Asero R: Expression of tissue factor by eosinophils in patients with chronic urticaria. Int Arch Allergy Immunol 2009, 148:170-4.

67. Parslew R, Pryce D, Ashworth J, Friedmann PS: Warfarin treatment of chronic idiopathic urticaria and angio-oedema. Clin Exper Allergy 2000, 30:1161-5.

68. Magerl M, Rother M, Bieber T, Biedermann T, Brasch J, Dominicus R, Hunzelmann N, Jakob T, Mahler V, Popp G, Schäkel K, Schlingensiepen R, Schmitt J, Siebenhaar F, Simon JC, Staubach P, Wedi B, Weidner C, Maurer M: Randomized, double-blind, placebo-controlled study of safety and efficacy of miltefosine in antihistamine-resistant chronic spontaneous urticaria. J Eur Acad Dermatol Venereol 2013, 27:e363-9.

doi:10.1186/1939-4551-7-31

Cite this article as: Greenberger: Chronic urticaria: new management options. World Allergy Organization Journal 2014 7:31.

\section{Submit your next manuscript to BioMed Central and take full advantage of:}

- Convenient online submission

- Thorough peer review

- No space constraints or color figure charges

- Immediate publication on acceptance

- Inclusion in PubMed, CAS, Scopus and Google Scholar

- Research which is freely available for redistribution

Submit your manuscript at www.biomedcentral.com/submit
C Biomed Central 